\title{
MEASURING CIVIC IDENTITY: DIFFICULTIES AND SOLUTION
}

\section{Petrovska I. R.}

\section{INTRODUCTION}

The Russian annexation of Crimea and partial occupation of Donbas, as well as the other problems, actualized the question of not formed civic identity of the large segments of Ukraine's population. Stable positive civic identity is the key to ensuring the national security of the state, in particular, its territorial integrity and consolidation of civil society, as it leads to psychological intolerance of citizens towards various kinds of external aggression (military, informational, economic, etc.). The growth of social problems, which is typical for recent years and partly explained by the war on the East of Ukraine, can not be handled only by the efforts of the government. Consolidated and coordinated actions of civil society (the psychological basis for the development of which is civic identity) are needed to assist the government in the matter of choosing the way of further strategic development that will provide citizens with the best protection from modern risks and dangers.

As a psychological phenomenon, civic identity is studied by Ukrainian and foreign scientists. Psychological essence of civic identity (Yates \& Youniss ${ }^{1}, 2006$; Hart, Richardson \& Wilkenfeld ${ }^{2}$, 2011; Zhadan $^{3}, 2017$; Khazratova ${ }^{4}, 2016$ ), its structure and levels (Cohen \&

\footnotetext{
${ }^{1}$ Yates, M., \& Youniss, J. (2006). Roots of Civic Identity. International Perspectives on Community Service and Activism in Youth. Cambridge University Press

${ }^{2}$ Hart, D., Richardson, C., \& Wilkenfeld, B. (2011). Civic Identity. Handbook of Identity. Theory and Research. 771-787

Zhadan, I.V. (2017). Empirychne doslidzhennia osoblyvostei hromadianskoi ta natsionalnoi samoidentyfiktsii molodi: bazovi poniattia ta pokaznyky [Empirical study of the peculiarities of civic and national self-identification of youth: basic concepts and indicators]. Scientific Studies on Social and Political Psychology, 39, 60-68

${ }^{4}$ Khazratova, N.V. (2016). Do pytannia pro psykholohichnu pryrodu hromadianskoi identychnosti ta yii dynamiku [On the Psychological Nature of Civic Identity and its Dynamics]. The Pedagogical Process: Theory and Practice. Series: Psychology. 3 (54), p. 79.
} 
Chaffee $^{5}$, 2013; Bezgina ${ }^{6}, 2013$; Petrovska $\left.{ }^{7}, 2019\right)$, the ratio of civic, ethnic, national and European identities (Hristova \& $\mathrm{Cekik}^{8}, 2013$; Taljunaite $^{9}$, 2013; Jimenez, Gorniak, Kosic, Kiss \& Kandulla ${ }^{10}$, 2004) are being examined, but the problem of psychological diagnosis of individual's civic identity has not been an object of any special studies and is still poorly developed.

\section{Civic Identity as a Complex Multilevel Personal Formation}

Civic identity implies an awareness and experience of own belonging to the community of citizens of a state. A state is a special form of organization of society that maintains its integrity, controllability and ability to satisfy the needs and interests of its members. A state can be considered as a social organization, as it possesses all of the corresponding features (community of people; social relationship is based on regulation of interaction, statuses, norms, division of labor in form the status-position system; presence of a coordinating body or a management system, interaction with outside world, etc.)

Self-determination in terms of civic identification is when a person identifies himself/herself with a member of the organization that is a state $^{4}$. Modern studies of organizational identity emphasize its dual nature (dual organizational identification) - identification with the working group and the organization as a whole (Vora \& Kostova ${ }^{11}$,

${ }^{5}$ Cohen, A., \& Chaffee, B. (2013). The relationship between adolescents' civic knowledge, civic attitude, and civic behavior and their self-reported future likelihood of voting. Education, Citizenship and Social Justice, 8(1), 43-57.

${ }^{6}$ Bezgina, N.V. (2013). K voprosu o postroenii strukturnoy modeli grazhdanskoy identichnosti [On the question of building a structural model of civic identity]. Psihosfera. Tula: TulGU. 8-14

${ }^{7}$ Petrovska, I. R. (2019). Etapy stanovlennia hromadianskoi identychnosti osobystosti [Stages of Civic Identity Formation]. Problems of Modern Psychology, 44, 212-233

${ }^{8}$ Hristova, L. \& Cekik, A. (2013). Between the ethnic and the civic identity - on the perceptions of the student population in the Republic of Macedonia. New Balkan Politics, 13, $45-70$

9 Taljunaite, M. (2013). From ethnic and civil identity towards state identity. FilosofijaSociologija, 24(4), 187-192.

${ }^{10}$ Jimenez, A., Gorniak, J., Kosic, A., Kiss, P., \& Kandulla, M. (2004). European and National Identities in EU's Old and New Member States: Ethnic, Civic, Instrumental and Symbolic Components. European Integration online Papers (EIoP), 8 (11)

${ }^{11}$ Vora D., \& Kostova, T. (2007). A model of dual organizational identification in the context of the multinational enterprise. Journal of Organizational Behavior, 28(3), 327-350 
2007; Bartels, Pruyn, De Jong \& Joustra ${ }^{12}$, 2006; Kreiner \& Ashforth ${ }^{13}$, 2004).

Therefore, the civic identity identification subjects (similar to the organizational identification subjects) are a community of citizens (similar to personnel of a company; community with common and typical challenges of their lives united by the territory where the laws of a particular state are effective) and the state (organization as a whole; the state as a social organization).

In the case of civic identification as organizational identification, there is a perception of one's belonging to the state (as an organization) and the community of citizens (as a group) in combination with specific forms of behavior and emotional contents. Important aspects of civic identification are self-categorization, awareness of own belonging to the state and the community of citizens; intra-group connections (perception of consolidation, commonality of interests and problems with other citizens); emotional valence (subjective assessment of a citizen's own affective experience related to living and functioning in the state). A prerequisite for the formation of a high-level civic identity is the approval of values of the state and emotional adherence to the state and fellow citizens.

Based on the principles of Social Identity and Self Categorization Theory (Tajfel \& Turner ${ }^{14}, 1986$ ), the approach of considering the civic identity as a kind of organizational identity (Petrovska ${ }^{15}, 2018$ ), the civic identity of a person can be defined as a complex multilevel personal formation that results from self-categorization, awareness (assigning meaning-value) of belonging to a community of citizens and the state (as its citizen) and subjective person's attitude (emotional and behavioral) to that membership.

12 Bartels J., Pruyn A., De Jong M., \& Joustra I. (2006). Multiple organizational identification levels and the impact of perceived external prestige and communication climate. Journal of Organizational Behavior, 28(2), 173-190

13 Kreiner, G., \& Ashforth, B. (2004). Evidence toward an expanded model of organizational identification. Journal of Organizational Behaviour, 25, 1-27

${ }^{14}$ Tajfel, H. \& Turner, J. C. (1986). The Social Identity Theory of Intergroup Behavior. Psychology of Intergroup Relations, 5, 7-24

15 Petrovska, I. R. (2018). Hromadianska identychnist yak riznovyd orhanizatsiinoi identychnosti [Civic identity as a type of Organizational identity]. Problems of Modern Psychology, 39, 244-257 
Civic identity as a multilevel personal phenomenon is manifested on the individual and social levels. Social level is divided according to the subjects of civic identification into the group (collective) and institutional (organizational) levels. Thus, civic identity levels are as follows:

- institutional («citizen - state») - inclusion of the individual into the legal, economic, axiological, symbolic space of the state; features of social perception of the state by the individual, the image of the state, trust and loyalty to it, etc.;

- group («citizen - community of citizens») - inclusion of the individual in a community of citizens backed by subjective feeling of inner unity with their compatriots, a sense of civic community (a sense of «We») - experiencing the relationship, solidarity, common historical destiny and typicality life problems with other citizens, etc;

- individual («I as a citizen») - a level of personal understanding of citizenship with emotional and value content; realization of the meaning and value of their lives, justification of own existence within this society.

Two interconnected systems are considered in the structure of civic identity: central (inner), represented by the cognitive, affective, and value components, and conative (outer), represented by the behavioral component. Central and conative components function as a whole and in their totality represent the civic identity and peculiarities of its functioning (Fig. 1).

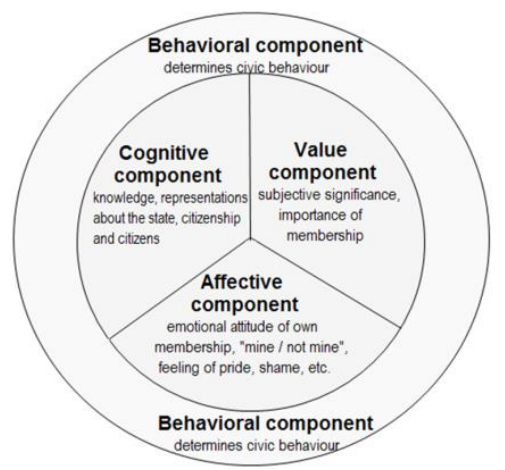

Fig. 1. Structural components of civic identity

Source: Own research 
Thus, civic identity is a unity of cognitive (awareness of own belonging to the state as its citizen and community of citizens, knowledge, figurative and symbolic representations about the state, citizenship and citizens), value (subjective significance, importance of membership, support (or not) state values and values of the civil community), affective (emotional attitude of own membership, «mine / not mine», feeling of pride, shame, patriotism, etc.) and behavioral (determines civic behaviour and defines the forms of activity (or inactivity) in relation to the state and citizens - activity, inclusion, affection / passivity, indifference, hostility, protest, confrontation, etc.; the readiness of the individual to act in accordance with the interests of the state and the civil community; civic participation / activity or passivity in advocacy of civil rights and values) components.

Formed civic identity is manifested in awareness of involvement in the community of citizens and the state, emotional attachment to them and acceptance of their values and goals at the behavioral level.

\section{Current Status and Problems of Civic Identity Measuring}

The overview of modern scientific works has revealed the most popular questionnaires today, namely Civic Engagement Scale (Doolittle \& Faul ${ }^{16}$, 2013), Civic Attitudes Scale (Mabry $\left.{ }^{17}, 1998\right)$, Civic Responsibility Scale (Astin \& Sax ${ }^{18}$, 1998), Civic Attitudes and Skills Questionnaire (Moely, Mercer, Ilustre, Miron \& McFarland ${ }^{19}$, 2002), Civic Identity Scale (Beaumont, Colby, Ehrlich \& Torney-Purta ${ }^{20}$, 2006). The problem of civic identity measuring of Ukraine's population today is the lack of, on the one hand, socio-culturally adapted variants of the above-mentioned questionnaires and, on the other hand, complex

${ }^{16}$ Doolittle, A., \& Faul, A. (2013). Civic Engagement Scale: A Validation Study. SAGE Open, 3, 1-7

${ }^{17}$ Mabry, J. (1998). Pedogogical variations in service-learning and student outcomes: How time, contact, and reflection matter. Michigan Journal of Community Service Learning, 5, 32-47.

${ }^{18}$ Astin, A., \& Sax, L. (1998). How undergraduates are affected by service participation. Journal of College Student Development, 39, 251-263

${ }^{19}$ Moely, B., Mercer, S., Ilustre, V., Miron, D., \& McFarland, M. (2002). Psychometric properties and correlates of the Civic Attitudes and Skills Questionnaire (CASQ): A measure of students' attitudes related to servicelearning. Michigan Journal of Community Service Learning, $8(2), 15-26$

${ }^{20}$ Beaumont, E., Colby, A., Ehrlich, T., \& Torney-Purta, J. (2006). Promoting political competence and engagement in college students. Journal of Political Science Education, 2(3), 249-270 
methods that assess the level of formation of structural components of civic identity, namely cognitive, value, conative and affective.

For instance, the Civic Identity Scale (Beaumont et al., 2006) was adapted from the Good Self-Assessment (GSA) and measured the centrality of moral characteristics to an individual's identity ${ }^{21}$. Civic Identity Scale authors have added elements of political identity to the elements of moral identity. Thus, the questionnaire contains 14 points, 6 of them are devoted to moral identity, 3 to political and 5 to personal characteristics. Questionnaire statements are rated from 1 (not important) to 4 (very important). The content of moral identity is represented in statements such as «fair», «stand for what I believe to be right», «compassionate, concerned about all people», «honest», «concerned about justice and human rights», «responsible»; political identity «interested in international issues», «politically involved», «interested in government decisions and policies»; other indicators - «smart», «creative, with a rich imagination», «rebellious», «friendly», «athletic, strong». Estimates of moral and political identity are calculated by averaging the relevant moral and political units. Higher scores correspond to a stronger civic identity. However, the question arises as to whether moral and political identities are the substantive components of civic identity?

State Identity Scale (Lewicka $\left.{ }^{22}, 2007\right)$, that was designed and socioculturally adapted to the Ukrainian sample by Polish researcherpsychologist Maria Lewicka, also should be mentioned. However, State Identity Scale represents levels of emotional attachment to one's national group (scale of patriotism) and glorification of one's national group (scale of nationalism), that characterizes features of national rather than civic identity. The decision on the level of formation of civic identity is made based on importance for the respondent to be Ukrainian or representative of another nation.

Scientists also use The Twenty Statements Test (TST) (Kuhn \& McPartland $^{23}$, 1954) to diagnose civic identity. However, the results of

\footnotetext{
${ }^{21}$ Porter, T. J. (2013). Moral and political identity and civic involvement in adolescents. Journal of Moral Education, p. 244.

${ }^{22}$ Lewicka, M. (2007). Regional Differentiation of Identity: A Comparison of Poland and Ukraine. Regional and Local Studies, 21-51

${ }^{23}$ Kuhn, M., \& McPartland, T. (1954). An Empirical Investigation of Self-Attitudes. American Sociological Review, 19(1), 68-76.
} 
our study, which was attended by 350 Ukrainian citizens aged 30-50 years, showed that only $8.5 \%$ of respondents actualize the role of a citizen for themselves. Thus, it can be argued that under more or less stable socio-political conditions, civic identity is usually not in an actualized state for the individual and does not dominate among other identities (gender-role, professional, etc.), which suggests that using this technique for civic identity diagnosis is a little informative.

The analysis of the existing methods leads to the conclusion that there is an urgent problem of creating psychodiagnostic tools, which would be based on the psychological concept of civic identity as a complex multilevel personal formation.

\section{Methodological Justification and «Level and Type} of Civic Identity» Questionnaire Development Procedure

The comprehensive study, which was conducted from November 2015 to December 2018, involved 1325 citizens aged 16-80 years from different regions of Ukraine.

In the first stage - preparation of the toolkit for civic identity study 353 citizens aged 18-79 years (113 male, 240 female) participated, 90 (25.5\%) of whom are in youth age, 150 (42.5\%) in age of early adulthood, $113(32.0 \%)$ in age of middle and late adulthood, in order to identify the categories most articulated in the discourse of citizens and related to awareness and experience of their belonging to the community of citizens and the state. For this purpose, the incomplete sentences test («As a citizen of Ukraine I...», «As a member of the community of citizens $I . . . »)$, associative test («What associations do you have with the statements: «I am a citizen of Ukraine», «I am a member of the community of citizens of Ukraine»?»), psycho-drawings and semistructured interviews were used. In the course of the content analysis, 419 indicators (sub-categories of analysis) were identified and then grouped into 10 categories as a result of semantic categorization. Qualitative and frequency analysis of the respondents' answers from the selected categories allowed us to make a list of 36 descriptors - items of the future questionnaire, but after expert evaluation ( 1 doctor and $5 \mathrm{PhD}$ of psychological sciences) and other validation procedures, their amount decreased to 24 (table. 1). 
Table 1

Questionnaire

\begin{tabular}{|c|c|c|c|c|}
\hline 1 & As a citizen, $I$ & $\begin{array}{l}\text { feel socially } \\
\text { unprotected }\end{array}$ & 3210123 & feel socially protected \\
\hline 2 & As a citizen, $I$ & passive & 3210123 & active \\
\hline 3 & As a citizen, $I$ & incompetent & 3210123 & competent \\
\hline 4 & As a citizen, $I$ & feel pride & 3210123 & feel shame \\
\hline 5 & As a citizen, $I$ & $\begin{array}{c}\text { aware of my rights and } \\
\text { duties }\end{array}$ & 3210123 & $\begin{array}{c}\text { not aware of my rights } \\
\text { and duties }\end{array}$ \\
\hline 6 & As a citizen, $I$ & $\begin{array}{l}\text { do not appreciate the } \\
\text { state }\end{array}$ & 3210123 & appreciate the state \\
\hline 7 & As a citizen, $I$ & patriotic & 3210123 & unpatriotic \\
\hline 8 & As a citizen, $I$ & sacrificial & 3210123 & selfish \\
\hline 9 & As a citizen, $I$ & $\begin{array}{l}\text { do not appreciate the } \\
\text { fellow citizens }\end{array}$ & 3210123 & $\begin{array}{c}\text { appreciate the fellow } \\
\text { citizens }\end{array}$ \\
\hline 10 & As a citizen, $I$ & $\begin{array}{l}\text { realize my own } \\
\text { responsibility for } \\
\text { society }\end{array}$ & 3210123 & $\begin{array}{c}\text { do not realize my own } \\
\text { responsibility for } \\
\text { society }\end{array}$ \\
\hline 11 & As a citizen, $I$ & do not influence events & 3210123 & influence events \\
\hline 12 & As a citizen, $I$ & solidary & 3210123 & not solidary \\
\hline 13 & As a citizen, $I$ & do not feel free & 3210123 & feel free \\
\hline 14 & As a citizen, $I$ & not indifferent & 3210123 & indifferent \\
\hline 15 & As a citizen, $I$ & $\begin{array}{l}\text { feel significant, } \\
\text { important }\end{array}$ & 3210123 & feel unimportant \\
\hline 16 & As a citizen, $I$ & $\begin{array}{c}\text { do not make any } \\
\text { efforts to develop the } \\
\text { state }\end{array}$ & 3210123 & $\begin{array}{l}\text { make efforts to } \\
\text { develop the state }\end{array}$ \\
\hline 17 & As a citizen, $I$ & disappointed & 3210123 & enthusiastic \\
\hline 18 & As a citizen, $I$ & feel strong & 3210123 & feel weak \\
\hline 19 & $I$ & $\begin{array}{c}\text { have no idea of myself } \\
\text { as a citizen of my state } \\
\text { and different from the } \\
\text { citizens of another } \\
\text { state }\end{array}$ & 3210123 & $\begin{array}{l}\text { have an idea of myself } \\
\text { as a citizen of the my } \\
\text { state and different } \\
\text { from the citizens of } \\
\text { another state }\end{array}$ \\
\hline 20 & As a citizen, $I$ & respect state symbols & 3210123 & $\begin{array}{c}\text { do not respect state } \\
\text { symbols }\end{array}$ \\
\hline 21 & As a citizen, $I$ & $\begin{array}{l}\text { ready to defend the } \\
\text { sovereignty and } \\
\text { integrity of the state }\end{array}$ & 3210123 & $\begin{array}{l}\text { not ready to defend } \\
\text { the sovereignty and } \\
\text { integrity of the state }\end{array}$ \\
\hline 22 & As a citizen, $I$ & feel insecure & 3210123 & feel safe \\
\hline 23 & As a citizen, $I$ & do not follow laws & 3210123 & follow laws \\
\hline 24 & $I$ & $\begin{array}{l}\text { have a clear view of } \\
\text { myself as a citizen }\end{array}$ & 3210123 & $\begin{array}{c}\text { have a vague } \\
\text { (uncertain) view of } \\
\text { myself as a citizen }\end{array}$ \\
\hline 25 & As a citizen, $I$ & want to emigrate & 3210123 & not want to emigrate \\
\hline 26 & $I$ & $\begin{array}{c}\text { do not consider myself } \\
\text { a European }\end{array}$ & 3210123 & $\begin{array}{c}\text { consider myself a } \\
\text { European }\end{array}$ \\
\hline 27 & $I$ & $\begin{array}{l}\text { do not consider myself } \\
\text { a citizen of the world }\end{array}$ & 3210123 & $\begin{array}{l}\text { consider myself a } \\
\text { citizen of the world }\end{array}$ \\
\hline
\end{tabular}


Therefore, the Questionnaire is based on the semantic differential measurement technique, where the respondent is offered the opposite (bipolar) statements that may apply to him/her as a citizen. The respondent should analyze each pair, determine which of two statements describes him/her more accurately and circle the digit corresponding to the degree (strength) of the expression of the characteristic, where 3 strong expression of the characteristic, 2 - medium, 1 - weak. «0» means that both statements in line are equally correct.

When processing the results, the answer for each item is turned into a 7 - point scale and summed in accordance with the key (Table 2) wholly (to determine the integral index of civic identity), or, if desired, for each subscale separately. Items 25-28 of the Questionnaire are not used for calculating the integral indicator but can be considered for additional information.

Table 2

Questionnaire Answer Key

\begin{tabular}{|c|c|c|}
\hline Scale & Direct Items & Indirect Items \\
\hline Integral Indicator of the & $1,2,3,6,9,11,13$, & $4,5,7,8,10,12,14$, \\
Civic Identity & $16,17,19,22,23$ & $15,18,20,21,24$ \\
\hline
\end{tabular}

\begin{tabular}{|c|c|c|}
\hline Subscales & Direct Items & Indirect Items \\
\hline Value component & $6,9,23$ & $7,10,12,20$ \\
\hline Affective component & $1,13,17,22$ & $4,15,18$ \\
\hline Behavioral component & $2,11,16$ & $8,14,21$ \\
\hline Cognitive component & 3,19 & 5,24 \\
\hline
\end{tabular}

\section{Psychometric Analysis and Interpretation of «Level and Type of Civic Identity» Questionnaire Diagnostic Indicators}

In the second stage - approbation of the Questionnaire (the psychosemantic study) - 972 citizens aged 16-79 participated ( $M=31.03$, б=11.57), 309 male (31.8\%), 663 female (68.2\%), $185(19.1 \%)-$ adolescence (16-20 years), $346(35.6 \%)$ - 21-30 years old (first phase of early adulthood), 242 (24.9\%) - aged 31-40 years (the second phase of early adulthood), 198 (20.4\%) - the age of middle and late adulthood. Among the surveyed persons, $239(24.6 \%)$ - have secondary education, $235(24.2 \%)$ - special and $498(51.2 \%)$ - higher education. 
Validity. Factor (structural) validity of the Questionnaire was determined through exploratory factor analysis by the principal components method with Varimax normalized rotation and then using confirmatory factor analysis as one of the methods of structural modeling. Results of factor analysis of the empirical data are represented in the 4-factor model (Table 3).

Table 3

Factor structure of the Questionnaire

\begin{tabular}{|c|c|c|c|c|c|}
\hline & \multirow{2}{*}{$\begin{array}{l}\text { Items (positive pole) } \\
\text { "As a citizen, I..." }\end{array}$} & \multicolumn{4}{|c|}{ Factors } \\
\hline & & 1 & 2 & 3 & 4 \\
\hline 1 & feel socially protected & & .64 & & \\
\hline 2 & active & & & .53 & \\
\hline 3 & competent & & & & .79 \\
\hline 4 & feel pride & & .52 & & \\
\hline 5 & aware of my rights and duties & & & & .61 \\
\hline 6 & appreciate the state & .67 & & & \\
\hline 7 & patriotic & .67 & & & \\
\hline 8 & sacrificial & & & .64 & \\
\hline 9 & appreciate the fellow citizens & .74 & & & \\
\hline 10 & realize my own responsibility for society & .51 & & & \\
\hline 11 & influence events & & & .67 & \\
\hline 12 & solidary & .57 & & & \\
\hline 13 & feel free & & .66 & & \\
\hline 14 & not indifferent & & & .57 & \\
\hline 15 & feel significant, important & & .53 & & \\
\hline 16 & make efforts to develop the state & & & .63 & \\
\hline 17 & enthusiastic & & .73 & & \\
\hline 18 & feel strong & & .71 & & \\
\hline 19 & $\begin{array}{l}\text { have an idea of myself as a citizen of the } \\
\text { my state and different from the citizens of } \\
\text { another state }\end{array}$ & & & & .54 \\
\hline 20 & respect state symbols & .82 & & & \\
\hline 21 & $\begin{array}{l}\text { ready to defend the sovereignty and } \\
\text { integrity of the state }\end{array}$ & & & .57 & \\
\hline 22 & feel safe & & .75 & & \\
\hline 23 & follow laws & .66 & & & \\
\hline 24 & have a clear view of myself as a citizen & & & & .54 \\
\hline & $\begin{array}{c}\text { ctor contribution to the total variance of } \\
\text { variables }(\%)\end{array}$ & 31.9 & 10.6 & 7.1 & 4.9 \\
\hline
\end{tabular}


The results presented in Table 3 suggest that the structure of the Questionnaire is empirically verified. According to the results of factor analysis, four factors with a total variance of $54.5 \%$ were distinguished: «Value Cmponent of Civic Identity» (factor 1), «Affective Cmponent of Civic Identity « (factor 2), «Behavioral Cmponent of Civic Identity « (factor 3) and «Cognitive Cmponent of Civic Identity « (factor 4).

Confirmatory factor analysis was used to test the hypothesis that civic identity is conditioned by four latent factors (questionnaire scales). The analysis was performed in Statistica 8.0 package using the GLS $\rightarrow$ ML method. The following criteria were used to analyze the consistency of the empirical data and the structural model: 1) $\chi 2$, if p-level $<0.05$, then there is no statistically significant difference between the observational data and the proposed model and $\chi 2 / \mathrm{df}$ ratio, which should not be greater than 2; 2) index RMS S.R. - an index that shows the quality of the model fit. If the RMS S.R. index value is less than 0.05, the fit is good enough.

The obtained model showed high compliance with the original data: $\chi 2=482.38 ; \mathrm{df}=246 ; \chi 2 / \mathrm{df}=1.96 ; \mathrm{p}=0.000000 ; \mathrm{RMS}$ S.R. $=0.0502$.

Thus, the Questionnaire contains 4 scales: "Value Component» (7 items), «Affective Component» (7 items), «Behavioral Component» (6 items), and «Cognitive Component» (4 items).

Factoring of the data of the Questionnaire «Level and Type of Civic Identity» showed that the factorial structure of the test was consistent with the theoretical model. Following questionnaires were used to test the convergent validity of the methodology: «The Level of Formation of Civic and Patriotic Qualities» (Timchyshyn \& Urusky $^{24}$, 2001) and «Civic Self-Awareness» (Ignatenko et al. ${ }^{25}, 1997$ ). It was found that the integral indicator of civic identity correlates $(\mathrm{p} \leq .05)$ with the indicator of «the level of formation of civic and patriotic qualities» $(\mathrm{r}=.53)$ and with the indicator of «civic self-awareness» $(r=.49)$, which confirms the construct validity of the Questionnaire.

24 Timchyshyn, O. \& Urusky, V. (2001). Robocha knyha vykhovatelya [Educator Workbook]. Ternopil: Aston, 295

25 Ihnatenko, P.R., Kosaryeva, N.I., Kryts'ka, L.V., \& Popluzhnyy, V.L. (1997). Vykhovannya hromadyanyna: psykholoho-pedahohichnyy ta narodoznavchyy aspekty [Education of the citizen: psychological, pedagogical and ethnographic aspects]. Kiev: Institute of Content and Learning Methods, 252 
Reliability. The internal reliability/consistency of the Questionnaire scales was verified using Cronbach's alpha, Split half reliability test (Spearman-Brown coefficient) and Gutman statistics. Test-retest reliability was examined with the participation of 166 citizens by retesting four weeks later. The verification results of the internal and test-retest reliability of the Questionnaire scales are given in Table 4.

Table 4

\section{Verification the internal and test reliabilityof the Questionnaire}

\begin{tabular}{|c|c|c|c|c|}
\hline Scale & $\begin{array}{c}\text { Cronbach's } \\
\text { alpha }(\alpha)\end{array}$ & $\begin{array}{c}\text { Split half } \\
\text { reliability }\end{array}$ & $\begin{array}{c}\text { Guttman } \\
\text { split-half } \\
\text { reliability }\end{array}$ & $\begin{array}{c}\text { Pearson } \\
\text { correlation } \\
\text { coefficient } \\
\text { (test-retest } \\
\text { reliability) }\end{array}$ \\
\hline Value Component & .846 & .853 & .847 & .612 \\
\hline Affective Component & .813 & .831 & .831 & .605 \\
\hline Behavioral Component & .789 & .808 & .808 & .513 \\
\hline Cognitive Component & .755 & .793 & .792 & .502 \\
\hline $\begin{array}{c}\text { Integral Indicator of the } \\
\text { Civic Identity }\end{array}$ & .826 & .873 & .856 & .528 \\
\hline
\end{tabular}

It should be noted that Cronbach's $\alpha$ is $>0.75$ on all scales of the Questionnaire, which indicates a high internal consistency of the scales and sufficiently high repeatability values (at $p \leq .01$ ) indicate the reliability of the test.

The Kolmogorov-Smirnov test (K-S test) was used to verify that the empirical distribution is normal (Table 5).

Table 5

Distribution characteristics of the Integral scale of the Questionnaire

\begin{tabular}{|c|c|c|c|c|c|}
\hline Scale & $\begin{array}{c}\text { Skewne } \\
\text { ss }\end{array}$ & $\begin{array}{c}\text { Std. er. } \\
\text { Skewne } \\
\text { ss }\end{array}$ & $\begin{array}{c}\text { Kurtos } \\
\text { is }\end{array}$ & $\begin{array}{c}\text { Std. er. } \\
\text { Kurtos } \\
\text { is }\end{array}$ & K-S \\
\hline $\begin{array}{c}\text { Integral Indicator of the Civic } \\
\text { Identity }\end{array}$ & -.206 & .101 & .068 & .202 & .042 \\
\hline
\end{tabular}

The presented results indicate the balance of the evaluation procedure and the potential of the technique to identify, differentiate the testing subjects by the levels of manifestation of the diagnosed characteristics 
and allow to describe the range of low, below average, average, above average and high values on the scales of the Questionnaire.

Cluster and discriminant analyses were used to correctly identify the boundaries of the ranges of civic identity levels.

Cluster analysis using tree clustering procedure and k-means method (after standardization) found five groups with different level of civic identity (Fig. 2).

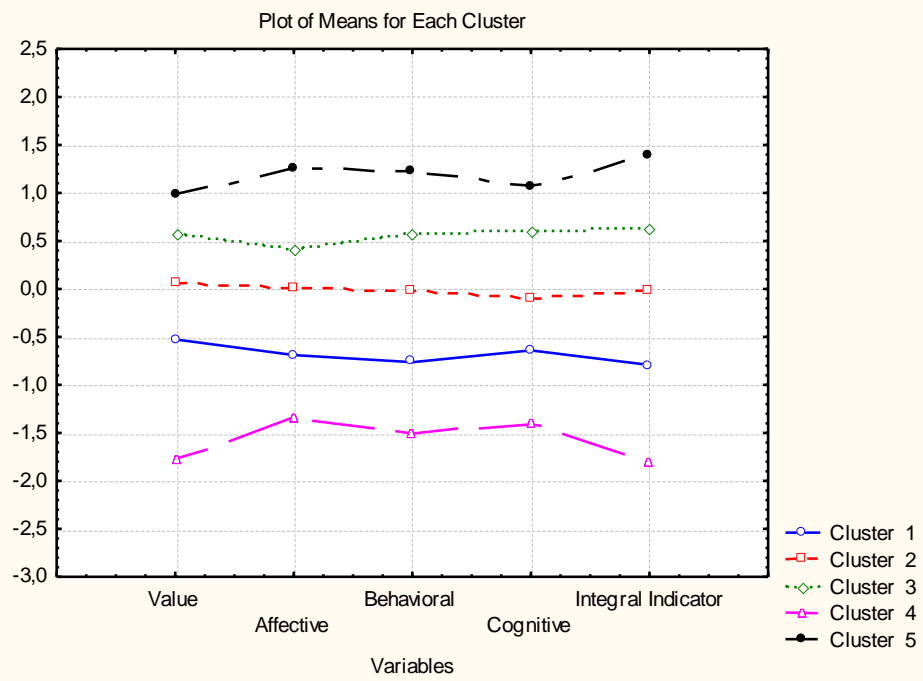

Fig. 2. Mean values of the civic identity components for different clusters

Source: Own research

As is known, one of the main tasks of cluster analysis is to develop a typology or classification. The specificity of the formation of components of the civic identity made it possible to create a typology of citizens: «devoted» (5th cluster $-15 \%)$, «moderate» (3rd cluster $29.4 \%$ ), «ambivalent» (2nd cluster $-20.7 \%$ ), «indifferent» (1st cluster $26.3 \%$ ) and «alienated» (4th cluster $-8.6 \%$ ) (Fig. 3). Significance (value)/insignificance, positive/negative attitude towards belonging to 
the state and community of citizens and forms of activity/inactivity in relation to the state and citizens made up the basis of the classification.

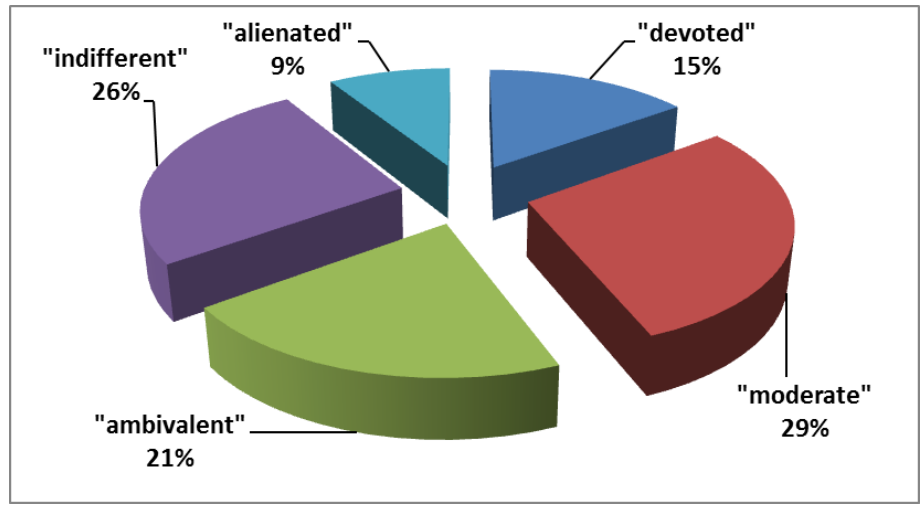

Fig. 3. Percentage of surveyed citizens

Source: Own research

with various types of civic identity

«Devoted» citizens have a high level of civic identity, realise their responsibility for the state and society, make efforts for its development, try to influence important events, and are ready to defend the independence and integrity of the state, which is considered to be one of the highest values.

«Moderate» citizens have above-average level of civic identity, a clear concept of themselves as citizens and manifest a certain level of solidarity with other compatriots. They value the state, statehood, fellow citizens, but are characterised by some restraint (of emotional and behavioral nature) in actualizing their social role of a citizen.

«Ambivalent» citizens are characterized by an average level of civic identity. They are characterized by instability and contradiction in their ideas about themselves as citizens: even recognizing fundamental state and civic values and socially important goals, declaring not indifference, but patriotism, awareness of their responsibility for civil society and the state, they do not feel sufficiently significant and capable of influencing important events, as a result, they do not strive to make efforts for the 
development of the state, are not ready to sacrifice anything for the sake of it, can be proud and ashamed that they are citizens of this state at the same time, are prone to come under different influences, so their participation in various forms of civic activity is usually chaotic, not fully understood, as they often act for the company and follow the crowd.

«Indifferent» citizens have below-average level of civic identity, are characterised by a reduced interest in state and socio-political events, usually take a neutral stance on important state matters, not too inclined to solidarity, exhibit passive-indifferent civil position, avoid any forms of civic activity and have a vague concept of themselves as citizens.

"Alienated» citizens have a low level of civic identity; desire to separate and distance themselves from the state and society as a whole, or to leave the country. This may indicate that there was no internalisation of such a social role, or this role (citizen) for them is alien and is being rejected and devalued consciously. Citizens of such type do not want to identify themselves with the community of citizens of their state - they are ready to change the Ukrainian civic identity for another (potential emigrants), since neither the state nor fellow citizens have any value for them, or they prefer to belong to the category «citizens of the world» (have no civic self-categorization).

The stepwise discriminant analysis was used to verify the correctness of the selected types. Wilks' Lambda statistic is used to indicate the statistical significance of the discrimination power in the current model. Its value varies from 1.0 (no discrimination) to 0.0 (full discrimination). In our case, discrimination between groups is highly significant (Wilks' Lambda: 0.0709, approx. F $(16.2945)=253.5707, \mathrm{p}<0.0000)$. The classification matrix (Table 6) presents the percentage of observations that were correctly classified for each cluster using the classification functions obtained.

The overall percentage of the classification correctness is $97.33 \%$, which indicates the high reliability of the division of persons into groups with different types of civic identity. This data is also confirmed by the analysis of the placement of the results in the space of canonical variables for the five groups of research subjects (Fig. 4). 
Table 6

Classification matrix

\begin{tabular}{|c|c|c|c|c|c|c|}
\hline Types & $\begin{array}{c}\text { Percent } \\
\text { Correct }\end{array}$ & $\begin{array}{c}\text { Indifferent } \\
\mathrm{p}=.26337\end{array}$ & $\begin{array}{c}\text { Moderate } \\
\mathrm{p}=.29424\end{array}$ & $\begin{array}{c}\text { Alienated } \\
\mathrm{p}=.08539\end{array}$ & $\begin{array}{c}\text { Devoted } \\
\mathrm{p}=.15021\end{array}$ & $\begin{array}{c}\text { Ambivalent } \\
\mathrm{p}=.20679\end{array}$ \\
\hline Indifferent & 96.4844 & 247 & 0 & 0 & 0 & 9 \\
\hline Moderate & 98.2518 & 0 & 281 & 0 & 0 & 5 \\
\hline Alienated & 91.5663 & 7 & 0 & 76 & 0 & 0 \\
\hline Devoted & 97.2603 & 0 & 4 & 0 & 142 & 0 \\
\hline Ambivalent & 99.5025 & 0 & 1 & 0 & 0 & 200 \\
\hline Total & 97.3251 & 254 & 286 & 76 & 142 & 214 \\
\hline
\end{tabular}

Root 1 vs. Root 2

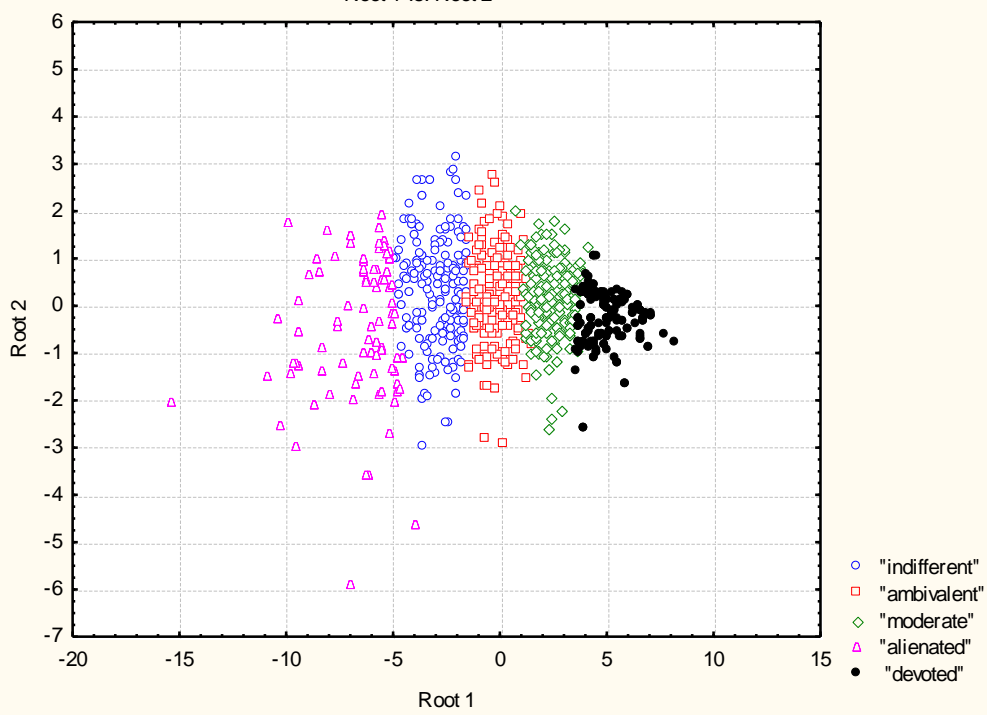

Fig. 4. Research results in the space of canonical variables for groups with different levels of civic identity (types)

Source: Own research

It is revealed that groups of people with different levels of civic identity are separated from each other, which gives grounds to claim that they are properly divided into types.

Average values and standard deviation of the components and Integral Indicator of Civic Identity for each cluster allowed us to determine low, below average, average, above average and high levels of 
civic identity. Thus, Table 7 allows determining the type of civic identity of an individual by the level of its formation.

Table 7

Determining the type of citizen

\begin{tabular}{|c|c|c|c|c|c|}
\hline \multirow{2}{*}{$\begin{array}{c}\text { Integral } \\
\text { Indicator of } \\
\text { the Civic } \\
\text { Identity }\end{array}$} & low & $\begin{array}{c}\text { below } \\
\text { average }\end{array}$ & average & $\begin{array}{c}\text { above } \\
\text { average }\end{array}$ & high \\
\cline { 2 - 6 } & $0 \div 93$ & $94 \div 114$ & $115 \div 126$ & $127 \div 142$ & $143 \div 168$ \\
\hline $\begin{array}{c}\text { The Type of } \\
\text { Citizen }\end{array}$ & Alienated & Indifferent & Ambivalent & Moderate & Devoted \\
\hline
\end{tabular}

Statistically significant differences were detected using one-way ANOVA and Scheffe's Test between types of civic identity and the desire to emigrate $(\mathrm{F}=59.84, \mathrm{p}=.0000)$.

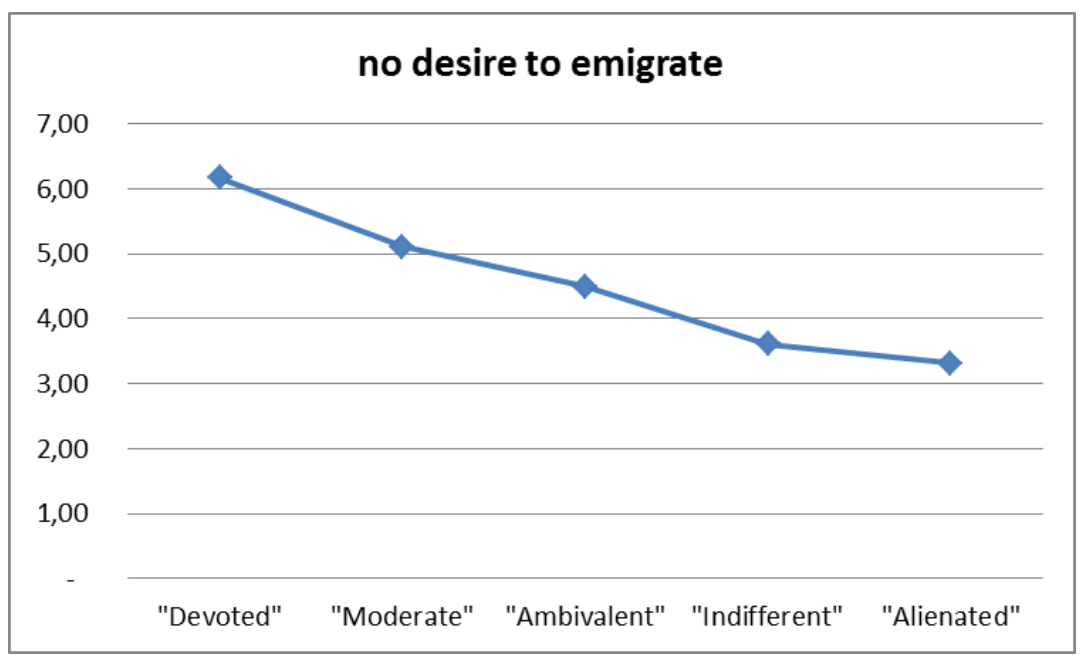

Fig. 5. Statistically significant differences of the scale "I want / do not want to emigrate" of persons with different types of civic identity Source: Own research

Thus, the desire to emigrate may be considered one of the criteria for validation of the Questionnaire. 
It is worth noting that the greatest danger is the desire of citizens to move to a permanent place of residence, which will also involve a profound process of changing lifestyle and daily practices, and, most importantly, it is a sign of a willingness to replace one's current civic identity with another. One of the motives for the desire to move abroad for permanent residence is a feeling of being alienated and disadvantaged in one's home country, poor involvement in social ties and relationships, which is, in fact, an everyday explication of social identity, in particular, civic identity.

\section{CONCLUSIONS}

The problem of measuring civic identity of an individual is extremely urgent, but it has not been the object of any special study and remains poorly developed. Only certain techniques of civic identity assessment, usually of schoolchildren and students, are represented in the scientific discourse. The overview of the existing methods of operationalization of civic identity suggests that the theoretical basis of the questionnaire construction is insufficiently substantiated, which results in the lack of a methodologically comprehensive diagnosis of civic identity as a complex multilevel personal formation.

The results of a comprehensive study, which was attended by 1325 Ukrainian citizens aged 16-80 years, are provided. In the first stage (preparation of the toolkit for the study of civic identity), most articulated in the discourse of citizens categories, related to the awareness and experience of their belonging to the community of citizens and the state, were distinguished and have been subject to qualitative (content) analysis and peer review. Content data became the basis for formulating questionnaire items.

In the second stage of the study, the approbation of the author's questionnaire was conducted, including the verification of reliability and validity. The reliability of the results is ensured by the use of methods of mathematical and statistical processing of empirical data, including correlation, cluster, variance, factor and discriminant analyses.

The positive results of the author's questionnaire approbation gave grounds for presenting the completed version with the key for calculating the results. 


\section{SUMMARY}

The civic identity of a person can be defined as a complex multilevel personal formation that results from self-categorization, awareness (assigning meaning-value) of belonging to a community of citizens and the state (as its citizen) and subjective person's attitude (emotional and behavioral) to that membership. Interpreting civic identity as a complex multilevel personal formation leads to change the diagnostic paradigm. In this case, the task of assessing the structural components of civic identity becomes relevant. The empirical study made it possible to determine most articulated in the discourse of citizens categories, related to the awareness and experience of their belonging to the community of citizens and the state, which formed the basis for the substantiation of the structural and semantic organization of the author's methodology. The author's Questionnaire «Level and Type of Civic Identity» is based on the semantic differential measurement technique and contains four scales (Cognitive Component, Value Component, Affective Component, Behavioral Component), which allows identifying the level of civic identity and the corresponding type of citizen («devoted», «moderate», «ambivalent», «indifferent» and «alienated»). The results of psychometric testing allow us to conclude that the developed Questionnaire is valid, reliable and can be used for further studies of civic identity.

\section{REFERENCES}

1. Astin, A., \& Sax, L. (1998). How undergraduates are affected by service participation. Journal of College Student Development, 39, 251-263.

2. Bartels J., Pruyn A., De Jong M., \& Joustra I. (2006). Multiple organizational identification levels and the impact of perceived external prestige and communication climate. Journal of Organizational Behavior, 28(2), 173-190.

3. Beaumont, E., Colby, A., Ehrlich, T., \& Torney-Purta, J. (2006). Promoting political competence and engagement in college students. Journal of Political Science Education, 2(3), 249-270.

4. Bezgina, N.V. (2013). K voprosu o postroenii strukturnoy modeli grazhdanskoy identichnosti [On the question of building a structural model of civic identity]. Psihosfera. Tula: TulGU. 8-14. (in Russian) 
5. Cohen, A., \& Chaffee, B. (2013). The relationship between adolescents' civic knowledge, civic attitude, and civic behavior and their self-reported future likelihood of voting. Education, Citizenship and Social Justice, 8(1), 43-57.

6. Doolittle, A., \& Faul, A. (2013). Civic Engagement Scale: A Validation Study. SAGE Open, 3, 1-7.

7. Hart, D., Richardson, C., \& Wilkenfeld, B. (2011). Civic Identity. Handbook of Identity. Theory and Research. 771-787.

8. Hristova, L. \& Cekik, A. (2013). Between the ethnic and the civic identity - on the perceptions of the student population in the Republic of Macedonia. New Balkan Politics, 13, 45-70.

9. Ihnatenko, P.R., Kosaryeva, N.I., Kryts'ka, L.V., \& Popluzhnyy, V.L. (1997). Vykhovannya hromadyanyna: psykholoho-pedahohichnyy ta narodoznavchyy aspekty [Education of the citizen: psychological, pedagogical and ethnographic aspects]. Kiev: Institute of Content and Learning Methods, 252. (in Ukrainian)

10. Jimenez, A., Gorniak, J., Kosic, A., Kiss, P., \& Kandulla, M. (2004). European and National Identities in EU's Old and New Member States: Ethnic, Civic, Instrumental and Symbolic Components. European Integration online Papers (EIoP), 8 (11).

11. Khazratova, N.V. (2016). Do pytannia pro psykholohichnu pryrodu hromadianskoi identychnosti ta yii dynamiku [On the Psychological Nature of Civic Identity and its Dynamics]. The Pedagogical Process: Theory and Practice. Series: Psychology. 3 (54), 78-84. (in Ukrainian)

12. Kreiner, G., \& Ashforth, B. (2004). Evidence toward an expanded model of organizational identification. Journal of Organizational Behaviour, 25, 1-27.

13. Kuhn, M., \& McPartland, T. (1954). An Empirical Investigation of Self-Attitudes. American Sociological Review, 19(1), 68-76.

14.Lewicka, M. (2007). Regional Differentiation of Identity: A Comparison of Poland and Ukraine. Regional and Local Studies, 21-51.

15. Mabry, J. (1998). Pedogogical variations in service-learning and student outcomes: How time, contact, and reflection matter. Michigan Journal of Community Service Learning, 5, 32-47.

16. Moely, B., Mercer, S., Ilustre, V., Miron, D., \& McFarland, M. (2002). Psychometric properties and correlates of the Civic Attitudes and Skills Questionnaire (CASQ): A measure of students' attitudes related to servicelearning. Michigan Journal of Community Service Learning, 8(2), $15-26$. 
17.Petrovska, I. R. (2019). Etapy stanovlennia hromadianskoi identychnosti osobystosti [Stages of Civic Identity Formation]. Problems of Modern Psychology, 44, 212-233. (in Ukrainian)

18.Petrovska, I. R. (2018). Hromadianska identychnist yak riznovyd orhanizatsiinoi identychnosti [Civic identity as a type of Organizational identity]. Problems of Modern Psychology, 39, 244-257 (in Ukrainian).

19.Porter, T. J. (2013). Moral and political identity and civic involvement in adolescents. Journal of Moral Education, 239-255.

20. Tajfel, H. \& Turner, J. C. (1986). The Social Identity Theory of Intergroup Behavior. Psychology of Intergroup Relations, 5, 7-24.

21. Taljunaite, M. (2013). From ethnic and civil identity towards state identity. Filosofija-Sociologija, 24(4), 187-192.

22. Timchyshyn, O. \& Urusky, V. (2001). Robocha knyha vykhovatelya [Educator Workbook]. Ternopil: Aston, 295. (in Ukrainian)

23. Vora D., \& Kostova, T. (2007). A model of dual organizational identification in the context of the multinational enterprise. Journal of Organizational Behavior, 28(3), 327-350.

24. Yates, M., \& Youniss, J. (2006). Roots of Civic Identity. International Perspectives on Community Service and Activism in Youth. Cambridge University Press.

25.Zhadan, I.V. (2017). Empirychne doslidzhennia osoblyvostei hromadianskoi ta natsionalnoi samoidentyfiktsii molodi: bazovi poniattia ta pokaznyky [Empirical study of the peculiarities of civic and national self-identification of youth: basic concepts and indicators]. Scientific Studies on Social and Political Psychology, 39, 60-68. (in Ukrainian)

\section{Information about the author:} Petrovska I. R., $\mathrm{PhD}$, Associate Professor at the Department of Psychology,

Ivan Franko National University of Lviv 1, Universytetska str., Lviv, 79000, Ukraine ORCID ID: https://orcid.org/0000-0001-7544-945X 